\title{
PENGARUH SISTEM INFORMASI MANAJEMEN (SIM) TERHADAP PENDIDIKAN
}

\author{
Anggun Susanti \\ UNIVERSITAS NEGERI PADANG \\ Indonesia \\ E-mail : anggunsusanti@gmail.com
}

\begin{abstract}
This article aims to describe the Management Information System (SIM), starting from the understanding of SIM, the purpose of SIM, the benefits of SIM and SIM elements, and the influence of SIM on Education. In the world of education the role of the SIM itself is needed to help the process of management of education management, which with the existence of good management of management, it is expected that the output can be better and the achievement of educational goals.

Keywords: (understanding of SIM, purpose of SIM, SIM benefits, SIM elements and the influence of SIM on education).

\section{Abstrak}

Artikel ini bertujuan untuk mendeskripsikan mengenai Sistem Informasi Manajemen (SIM), mulai dari pengertian SIM, tujuan SIM, manfaat SIM dan unsur-unsur SIM, serta pengaruh SIM terhadap Pendidikan. Dalam dunia pendidikan peran dari SIM itu sendiri sangatlah dibutuhkan untuk membantu proses pengeloaan manajemen pendidikan, yang mana dengan adanya pengeloaan manajemen yang baik, diharapkan outputnya dapat lebih baik serta tercapainya tujuan pendidikan.
\end{abstract}


Keywords: (pengertian SIM, tujuan SIM, manfaat SIM, unsure-unsur SIM dan pengaruh SIM terhadap pendidikan).

\section{PENDAHULUAN}

Sistem Informasi Manajemen merupakan salah satu aspek penting demi kemajuan dalam dunia pendidikan, yang mana dengan adanya SIM ini, sangat membantu proses manajemen yang ada disekolah, membantu petugas manajerial dalam mengumpulkan berbagai informasi yang dibutuhkan, mulai dari informasiinformasi terdahulu hingga informasi terbaru saat sekarang ini. Namun, seperti yang kita ketahui bahwa pengimplementasiannya tidak berjalan lancar, masih banyak kita temui para pengelola pendidikan yang tidak memanfaatkan SIM ini dengan sebaik-baiknya, yang menyebabkan tidak optimalnya lembaga pendidikan atas pengelolaan fungsi-fungsi manajemen dalam dunia pendidikan

Oleh karena itu sangat diharapkan agar SIM ini dapat berkembang dari masa ke-masa, selalu menciptakan teknologi baru yang lebih canggih dan mutakhir, serta adanya perbaruan yang menuntun pendidikan kearah yang lebih baik kedepannya. Seiring dengan berkembangnya zaman maka semakin tinggi juga kebutuhan manusia akan pendidikan, oleh karna itu teknologi informasi harus berjalan seiring dengan perkembangan zaman tersebut dan memberikan informasi yang lebih cepat, akurat dan terpercaya.

Jadi kesimpulannya ialah Sistem Informasi Manajemen merupakan suatu sistem yang dibentuk/ dirancang sebagai penyedia data atau informasi, yang berguna sebagai faktor pendukung dalam pengambilan keputusan pada kegiatan manajemen yanga ada dalam suatu organisasi

\section{PEMBAHASAN}

\section{A. Definisi Sistem Inforemasi Manajemen (SIM)}

Menurut (Lipursari, 2013) Sistem merupakan suatu jaringan kerja dari prosedur yang saling berhubungan, berkumpul, dan bersama-sama dalam 
melakukan sebuah kegiatan atau dalam hal penyelesaian suatu sasaran tertentu. Sedangkan informasi merupakan suatu data yang telah diklasifikasikan atau diolah serta diinterprestasi untuk digunakan dalam proses pengambilan keputusan.

Sistem Informasi Manajemen merupakan suatu sistem berbasis komputer

yang didalamya telah tersedia informasi bagi beberapa pemakai dengan kebutuhan yang sama, Mc.Leod (Yakub, 2012). Serta dapat diartikan juga , bahwa Sistem Informasi Manajemen adalah suatu sistem yang didalamnya terdapat beberapa komponen yang terkait satu sama lain. Komponenkomponen tersebut akan saling terkoordinasi atau saling bekerja sama dengan baik agar tercapainya tujuan yang diinginkan (Agustiandra \& Sabandi, 2019)

Jadi kesimpulannya ialah Sistem Informasi Manajemen merupakan suatu sistem yang dibentuk/ dirancang sebagai penyedia data atau informasi, yang berguna sebagai faktor pendukung dalam pengambilan keputusan pada kegiatan manajemen yanga ada dalam suatu organisasi.

\section{B. Tujuan Sistem Informasi Manajemen (SIM)}

Tujuan dari Sistem Informasi Manajemen ialah sebagai berikut :

1. Membantu pengelolaan manajemen dalam hal penyediaan informasi yang dibutuhkan dalam perhitungan harga pokok jasa, produk dan tujuan lainnya.

2. Membantu manajemen dalam penyediaan informasi yang digunakan dalam proses perencanaan, pengendalian, pengevaluasian dan perbaikan yang berkelanjutan.

3. Menyediakan berbagai macam informasi yang digunakan dalam proses pengambilan keputusan.

Dari ketiga tujuan diatas mendeskripsikan bahwa manajer dan pemakai lainnya butuh untuk mendapatkan akses menuju informasi akuntansi manajemen serta mengetahui bagaimana cara kerjanya.informasi akuntansi 
manajemen bisa membantu mereka mengidentifikasi suatu masalah, menyelesaikan masalah dang megevaluasi suatu kinerja (informasi ini dibutuhkan dan digunakan dalam semua tahapan manajemen, mulai dari perencanaan, pengendalian dan pengambilan keputusan).

Sistem Informasi Manajemen (SIM) juga memiliki tujuan untuk dapat memenuhi informasi kebutuhan umum baik dari suatu suatu perusahan maupun sekolah. Dapat kita lihat bahwa sekolah memiliki suatu kebutuhan yang sangat kompleks, oleh sebab itu diperlukan suatu terobosan yang dapat mengatur dan menghubungkan semua level hirarki manajemen yang ada di sekolah.

\section{Manfaat Sistem Informasi Manajemen (SIM)}

Beberapa manfaat SIM ialah sebagai berikut :

1. Membantu dalam meningkatkan efisiensi serta efektifitas secara lebih akurat dan realtime.

2. Membantu mempermudah kerja pengelola manajemen dalam melakukan perencanaan, pengawasan, pengarahan, dan pendelegasian kerja teruntuk semua departemen yang memiliki hubungan atau koordinasi.

3. Mampu meningkatkan kuaitas sumber daya manusia (SDM), karda adanya unit-unit kerja yang saling terkoordinasi dan sistematis.

4. Mampu meningkatkan produktivitas serta mampu meghemat biaya yang di keluarkan dalam suatu organisasi.

Manfaat lainnya dari Sistem Informasi Manajemen yaitu :

1. Mampu meningkatkan aksesibilitas data yang tersedia secara tepat waktu dan akurat bagi setiap pemakai, tanpa harus adanya perantara dari sistem informasi.

2. Mampu mengembangkan proses perencanaan dan kegiatan manajemen yang efektif.

3. Adanya efisiensi kebutuhan sekolah. 
4. Adanya keterjaminan keamanan data karena menggunakan sistem arsiping.

5. Mampu memperbaiki kinerja serta produktifitas di setiap jenjang manajemen.

6. Sekolah menggunakan SIM untuk mengolah transaksi yang ada, mengurangi biaya serta menghasilkan pendapatan sebagai salah satu produk atau pelayanan mereka.

7. Sistem informasi mendukung manajerial dalam proses pengambilan keputusan.

8. Mampu membantu tercapainya keunggulan strategis.

\section{Unsur-Unsur Sistem Informasi Manajemen (SIM)}

Sistem informasi manajemen memiliki tiga unsure utama, yaitu:

1. Menerima data sebagai suatu masukan (input)

2. Memproses data dengan melakukan suatu perhitungan, penggabungan unsure data, pemutakhiran perkiraan dan lain-lain.

3. Memperoleh informasi sebagai keluaran (output).

Prinsip diatas berlaku baik untuk system informasi manual, elektomekanis ataupun komputer.

Ada beberapa unsure SIM lainnya, yaitu :

1. System manusia atau mesin

Adanya perpaduan atau kerjasama antara manusia dan mesin. Yang mana manusia hanya menjadi suatu operator yang mengandalkan mesin untuk bekerja, atau sebaliknya manusia yang lebih dominan dan mengandalkan mesin sebagai pendukung pekerjaan saja seperi halnya sebagai penyedia perhitungan atau mencari data.

2. System terpadu

Adanya panduan terencana dari berbagai penerapan yang layak serta efektif dan efisien.

3. System operasi 
Untuk dapat mengoperasikan pengolahan transaksi pada suatu system yang mutakhir dan menuju pada pengumpulan data secara online. Kemampuan untuk mendapatkan data secara online sangat besar peranannya dalam mendukung operasi.

\section{E. Pengaruh Sistem Informasi Manajemen (SIM) Terhadap Pendidikan}

Menurut (Agustiandra \& Sabandi, 2019) Sistem Informasi Manajemen Akademik ialah segala bentuk hasil interaksi anatara elemen-elemen di lingkungan akademik untuk menghasilkan suatu informasi yang nantinya dijadikan sebagai landasan dalam pengambilan keputusan, melakasanakan tindakan, baik dari pelaku proses itu sendiri maupun dari pihak luar sekolah.

Peran Sistem Informasi Manajemen dalam dunia pendidikan menacukup banyak sektor, diantaranya :

1. Koneksi dan setting

Koneksi dan setting ini ialah koneksi database sekolah, setting tahun ajaran, dan setting kurikulum. Pihak pengelola manajemen disekolah melakukan setting terhadap tahun ajaran dan kurikulumnya dengan mudah melalui datambase yang tersistematis, sehingga mempermudah stakeholders sekolah yang ingin melakukan akses tersebut.

2. Pengelolaan kesiswaan

Merupakan pengolahan data-data yang berhubungan dengan siswa, misalnya track record seorang siswa dalam pelanggaran disiplin, data prestasi siswa, data siswa yang mendapatkan beasiswa, data mutasi siwa, dan data alumni-alumni sekolah tersebut.

3. Pengelolaan akademik

Pengelolaan data nilai hasil ujian secara periodic, data nilai kurikuum, data nilai KBK, data absensi, data penyuluhan dan data bimbingan, dan lain-lain.

4. Pengelolaan data guru dan karyawan 
Mengelola biodata guru dan karyawan, riwayat pendidikannya, data keluarganya, dan data pendidikan tambahan apa yang dibutuhkan oleh guru.

Pengimplementasian system informasi manajemen pendidikan yaitu sebagai pendukung dari pross fungsi manajemen seperti perencanaan, pengorganisasian, penggerrakan dan pengontrolan, untuk menunjang tercapainya sasaran dan tujuan dari fungsi operasional di suatu lembaga pendidikan.

\section{KESIMPULAN DAN SARAN}

\section{A. Kesimpulan}

System Informasi Manajemen adalah suatu sistem yang dibentuk/ dirancang sebagai penyedia data atau informasi, yang berguna sebagai faktor pendukung dalam pengambilan keputusan pada kegiatan manajemen yanga ada dalam suatu organisasi.

Pengembangan Sistem Informasi Manajemen yang lebih canggih berbasis computer memerlukan sumber daya manusia yang memiliki kemampuan tinggi serta mesin yang mutakhir, serta adanya partisipasi aktif dari kepala sekolah. Semua system informasi ada unsure utama yaitu adanya input, proses, serta output.

\section{B. Saran}

Penulis menyarankan agar sehendaknya setiap sekolah harus menerapkan Sistem Informasi Manajemen yang lebih baik dan benar karena sangat berpengaruh terhadap perkembangan serta kestabilan pengelolaan manajemen suatu sekolah dalam pengambilan keputusan. 


\section{DAFTAR RUJUKAN}

Agustiandra, V., \& Sabandi, A. (2019). Persepsi Guru Terhadap Penerapan Sistem Informasi Manajemen Akademik Di Sekolah Menengah Kejuruan (Smk) Negeri 3 Padang. Jurnal Bahana Manajemen Pendidikan, 8(1), 1-8.

Lipursari, A. (2013). Peran Sistem Informasi Manajemen (Sim) Dalam Pengambilan Keputusan. Jurnal Stie Semarang, 5(1).

Yakub. (2012). Pengantar Sistem Informasi. Yogyakarta: Graha Ilmu. 